\title{
Gene expression profile as a prognostic factor in high-grade gliomas
}

\author{
TOMASZ CZERNICKI ${ }^{1}$, JOLANTA ZEGARSKA ${ }^{2}$, LESZEK PACZEK ${ }^{2}$, \\ BOZENA CUKROWSKA ${ }^{3}$, WIESLAWA GRAJKOWSKA ${ }^{3}$, AGNIESZKA ZAJACZKOWSKA ${ }^{3}$, \\ KAZIMIERZ BRUDZEWSKI ${ }^{4}$, JAN ULACZYK ${ }^{5}$ and ANDRZEJ MARCHEL ${ }^{1}$
}

\author{
${ }^{1}$ Department of Neurosurgery, Banacha street No. 1A, 02-097 Warsaw; ${ }^{2}$ Department of Immunology, \\ Transplantology and Internal Medicine, Nowogrodzka street No. 59, 02-006 Warsaw, Medical University of Warsaw; \\ ${ }^{3}$ Department of Pathology, Children's Memorial Health Institute, Dzieci Polskich boulevard No. 20, 04-730 Warsaw; \\ ${ }^{4}$ Department of Chemistry, Koszykowa street No. 75, 00-662 Warsaw; ${ }^{5}$ Department of Physics, \\ Noakowskiego street No. 3, 00-664 Warsaw, Warsaw University of Technology, Poland
}

Received June 13, 2006; Accepted August 2, 2006

\begin{abstract}
Some clinical factors have been useful in predicting prognosis in high-grade gliomas, however, unexpected differences in survival time have generated attempts to search for more precise parameters. It is clear that tumour behaviour depends mostly on gene alterations. Known single gene alterations failed to accurately define survival time, however, recently, the gene profiling based on microarray technology has raised hopes. Our aim was to assess whether the genetic predictor exceeds clinical parameters in the prognosis of malignant gliomas. We performed gene expression analysis of 28 gliomas (3 grade II, 10 grade III and 15 grade IV, according to WHO classification), and 5 control, normal brain samples, using Clontech oligonucleotide arrays with 3,757 known genes. The signal-to-noise statistics was used to separate classes, and the leave-one-out method was used to assess the smallest number of genes make it clear with a minimal cross-validation error. All gliomas, or only high-grade tumours, were clearly separated from the normal brain samples using 7 or 9 most differentially expressed genes. Hierarchical clustering failed, but the fuzzy c-means method was useful in high-grade gliomas to find a gene prediction model, which, with clinical factors, was assessed in survival analysis. Univariate analysis demonstrated that age, WHO grade (IV vs. III), radiation dose ( $\geq 50$ Gy vs. 42 Gy), postoperative KPS score (100 points vs. others), neurological deficit as the first sign of the disease vs. others, and gene expression profile were significant predictors of survival. In multivariate analysis, the gene expression profile remained the only independent
\end{abstract}

Correspondence to: Dr Tomasz Czernicki, Department of Neurosurgery, Medical University of Warsaw, Banacha Street No. 1A, 02-097 Warsaw, Poland

E-mail: tczernicki@wp.pl

Key words: glioma, microarray, glioblastoma, astrocytoma, prognostic factor, survival predictor $(\mathrm{p}=0.007)$. Thus, our conclusion is that gene expression pattern predicts outcome in high-grade gliomas independently of other factors.

\section{Introduction}

Despite aggressive treatment with surgery, radio- and chemotherapy, prognosis for patients with malignant gliomas is still poor. The mean survival time in glioblastomas is $<1$ year, in anaplastic astrocytomas up to 3 years. However, survival does vary among patients (1-8). An unexpected clinical course reflects primarily biological differences between these tumors. A few clinical factors such as age, Karnofsky performance status, extent of tumour resection, have been identified as useful in assessing the prognosis $(4,6,7,9-11)$. However, genetic heterogeneity of the tumours may exert the most significant influence on differences in the survival period $(3,12)$. At present, our attempts have been focused on identifying those genetic alterations. Many studies have concentrated on genes such as EGFR, PTEN, TP53, CDKN2A, MDM2, and apoptotic and proliferation indices have been conducted; however, a single gene seems to be rarely predictive of survival, and opposing results have been reported. In other words, known differences in gene alterations, found in astrocytomas and glioblastomas, cannot be directly translated into knowledge of prognosis. For example, views on the influence of TP53 mutations on survival are divergent; some researchers advocate this association (8,13-15), others do not (9,12,16-26). Overexpression of MDM2 is also a poor predictor in some $(3,24,27)$, but not in all studies $(19,22)$. Losses of heterozygosity on $1 \mathrm{p}$ and $19 \mathrm{q}$ in tumours of oligodendroglial origin are an exception, when researchers agree as to their favourable impact on susceptibility to chemotherapy and survival time (26,28-32). However, this reverses to the previous stage of divergent results in the case of PTEN alterations. PTEN loss or mutations reduce survival in anaplastic astrocytomas and anaplastic oligodendrogliomas $(8,26,30,31,33,34)$, but not always in glioblastomas $(8,12,13,16,19,33-36)$. Similarly, an overexpression or 
Table I. Demographic and clinical data.

\begin{tabular}{|c|c|c|c|c|}
\hline \multirow{2}{*}{$\begin{array}{l}\text { Patient } \\
\text { demographic } \\
\text { and clinical data }\end{array}$} & \multicolumn{2}{|c|}{$\begin{array}{l}\text { All WHO grades } \\
\qquad(\mathrm{n}=28)\end{array}$} & \multicolumn{2}{|c|}{$\begin{array}{c}\text { WHO grade } \\
\text { III + IV }(n=25)\end{array}$} \\
\hline & $\mathrm{n}(\%)$ & Range & $\mathrm{n}(\%)$ & Range \\
\hline \multicolumn{5}{|l|}{ Age (years) } \\
\hline$<40$ & $9(32.1)$ & & $7(28)$ & \\
\hline$\geq 40$ & $19(67.9)$ & & $18(72)$ & \\
\hline$<60$ & $20(71.4)$ & & $17(68)$ & \\
\hline$\geq 60$ & $8(28.6)$ & & $8(32)$ & \\
\hline Mean & 49.8 & $23-79$ & 51.2 & $23-79$ \\
\hline \multicolumn{5}{|l|}{$\begin{array}{l}\text { Duration of } \\
\text { symptoms (weeks) }\end{array}$} \\
\hline Mean & 13.3 & & 13.6 & \\
\hline Median & 5.5 & $2-112$ & 6 & $2-112$ \\
\hline \multicolumn{5}{|l|}{ Sex } \\
\hline Male & $18(64.3)$ & & $17(68)$ & \\
\hline Female & $10(35.7)$ & & $25(32)$ & \\
\hline \multicolumn{5}{|l|}{ EOR } \\
\hline GTR & $14(50)$ & & $12(48)$ & \\
\hline STR & $14(50)$ & & $13(52)$ & \\
\hline \multicolumn{5}{|l|}{ Postoperative KPS } \\
\hline 100 points & $13(46.4)$ & & $12(48)$ & \\
\hline$\leq 90$ points & $15(53.6)$ & & $13(52)$ & \\
\hline \multicolumn{5}{|l|}{ Radiation dose } \\
\hline $\begin{array}{l}\text { Higher dose: } \\
50 \text { or } 60 \text { Gy }\end{array}$ & $17 / 27(63)$ & & $16(64)$ & \\
\hline $\begin{array}{l}\text { Lower dose: } \\
42 \mathrm{~Gy}\end{array}$ & $10 / 27(37)$ & & $9(36)$ & \\
\hline \multicolumn{5}{|l|}{ Chemotherapy } \\
\hline Yes & $19(67.9)$ & & $19(76)$ & \\
\hline No & $9(32.1)$ & & $6(24)$ & \\
\hline \multicolumn{5}{|l|}{$\begin{array}{l}\text { First symptom } \\
\text { of disease }\end{array}$} \\
\hline Deficit & $6(21.4)$ & & $6(24)$ & \\
\hline Epileptic seizure & $8(28.6)$ & & $6(24)$ & \\
\hline
\end{tabular}

GTR, gross total resection; STR, subtotal resection; KPS, Karnofsky performance scale.

amplification of EGFR does not influence survival in glioblas-tomas $(3,9,12,13,16,22,34-37)$, except in the elderly patients in whom it is related to a more favourable prognosis $(8,9,25)$. Microarrays offer new opportunities in this area by permitting simultaneous evaluation of expression of thousands of genes. Successful attempts were made to find gene expression profiles correlated with prognosis in many tumours (38-41), recently, including gliomas $(12,42-44)$. The aim of the present study was to identify, using microarray technology, a gene expression profile which might be prognostic in high-grade gliomas, and to compare its strength with known clinical factors.

\section{Materials and methods}

Patients samples. Tumour and normal brain samples were obtained at open-craniotomy surgery performed at Medical University of Warsaw, between 2002 and 2004; the samples were snap-frozen on dry-ice and stored at $-80^{\circ} \mathrm{C}$ until use. The study was approved by the Institutional Review Board. All glioma samples were obtained at primary operation with no prior patient history of radio- or chemotherapy. Normal brain samples were obtained from patients operated on for longlasting drug-resistant epilepsy. Histopathological diagnoses (according to the WHO classification) were made by two independent neuropathologists, with consensus reached in all cases. A total of 28 gliomas were assessed: 3 grade II tumours (2 fibrillary astrocytomas, 1 oligoastrocytoma), 10 grade III tumours (3 anaplastic oligodendrogliomas, 7 anaplastic astrocytomas) and 15 grade IV tumours (9 multiform glioblastomas, 3 giant cell glioblastomas, 3 gliosarcomas). Control tissues consisted of the white matter from resected temporal poles obtained from 5 patients with hippocampal sclerosis. All glioma patients, except one with a resected fibrillary astrocytoma (GTR), were irradiated with a dose of 42 - 62 Gy; 19 out of 25 patients with high-grade gliomas received also chemotherapy [CCNU (12), temozolomide (1), both agents, successively (4), PCV (1), PCV with temozolomide (1)]. Demographic and clinical data from our cohort of patients are shown in Table I. Median follow-up was 57.4 weeks, range: 14.4-137.1 weeks (median in high-grade subgroup: 53.7 weeks). By the end of the study 16 patients had died (high-grade gliomas); median follow-up in the deceased patients was 31.6 weeks; range: 14.4-71.4 weeks. In the survivors' group, the median follow-up was 100.4 weeks, in patients with high-grade gliomas 83.4 weeks; range in both groups: 55.6-137.1 weeks.

Isolation of total RNA. Total RNA was isolated by means of a modified method developed by Chomczynski and Sacchi (45). The frozen samples were placed on dry-ice, ground using a mortar and pestle, and subsequently, homogenized in TRIzol (Invitrogen, Carlsbad, USA) using a power homogenizer (IKA Labortechnik, Staufen, Germany). After a 5-min incubation with TRIzol and a further 2-min incubation with added chloroform (Sigma-Aldrich, St. Louis, MO, USA), the samples were centrifuged. The resulting upper aqueous phase was mixed with an equal amount of isopropyl alcohol (SigmaAldrich), and RNA was precipitated at $-20^{\circ} \mathrm{C}$ overnight. On the subsequent day, the samples were centrifuged, the supernatant was removed, ice-cold $75 \%$ ethanol was added (Sigma-Aldrich), and the samples were centrifuged again. After removing the supernatant, air-dried RNA pellets were dissolved in deionised, RNAase free water. RNA integrity and purity were verified by electrophoresis on agarose gel (Gibco-BRL Life Technologies, Gaithersburg, USA) and by UV/Vis spectrophotometry (Perkin-Elmer, Uberlingen, Germany) using RNA dissolved in TE (Applichem, Darmstadt, Germany). The presence of high-quality, undegraded RNA was established when intensity of 28S rRNA band was twice that of 18S rRNA with no streaking on the lower part of the sample lane, and the range of the absorbance $\mathrm{A}_{260} / \mathrm{A}_{280}$ ratio was: 1.8-2.1. 
cDNA microarray hybrizydation and scanning. Fluorescently labelled cDNA probes were generated using, at the most, $12 \mu \mathrm{g}$ of the total RNA by reverse transcription in the presence of aminoallyl-dUTP, subsequently, followed by a coupling reaction to Cy-3 dye (Amersham Pharmacia, Piscataway, USA) according to the manufacturer's protocol (Clontech \# K-1860-1, BD Biosciences, Palo Alto, CA, USA). Probes were denatured and hybridized to glass microarrays with 3,757 known genes (Clontech \# 7910-1, BD Biosciences) at $50^{\circ} \mathrm{C}$ overnight. The following day, the slides were washed four times successively: once, in a wash solution supplied by the manufacturer twice, in a mixture: $1 / 10$ wash solution $+9 / 101 \mathrm{X}$ SSC (Sigma-Aldrich) and once in 1X SSC. Finally, the slides were spin-dried. The fluorescent intensity was assessed by scanning slides with a $5-\mu \mathrm{m}$ resolution at a light wavelength of $532 \mu \mathrm{m}$, and a voltage of 650 PMT using a GenePix 4000B scanner, and the images were processed with GenePix Pro 3.0 software (Axon Instruments, Union City, USA).

Data analysis. Raw data as *.gpr format files were loaded to Gene Spring 6.1 (Silicon Genetics, Redwood City, USA) with background subtraction from signal intensities. Next, the values $<0.01$ were set to 0.01 . Each measurement was divided by the median of all measurements in the sample marked as present or marginal; at the subsequent stage, each measurement for each gene in glioma samples was divided by the median of corresponding gene's measurements in the control samples. The data were next imported to MatLab ver. 6.5.0.180813a release 13 (MathWorks, Natick, USA) and normalized again by dividing gene measurements by the mean of a corresponding gene's measurements in all samples. Genes correlated with particular distinctions were identified using the signal-tonoise statistic: $d=\left(\mu_{1}-\mu_{2}\right) /\left(\delta_{1}+\delta_{2}\right)$; where $\mu$ and $\delta$ represent the mean and standard deviation of expression, for two comparable classes, respectively. The expression level of each gene relative to the mean expression level across all samples is represented by an appropriate colour. Red colour represents expression greater than the mean, and blue represents expression less than the mean. The intensity of each colour represents the magnitude of deviation from the mean. Value of these distinctions was confirmed by means of SVM with the leave-one-out cross-validation method, whereby a training set of all samples, but one, in that distinction, has been used to predict the class of a randomly withheld sample, and the accuracy rate was recorded. Starting from 30 genes (15 most over- and 15 most underexpressed) in a respective distinction, subtracting one gene by turn, we tried to find the minimum number of genes separating the two classes with good accuracy.

Survival prediction models were performed using two methods: hierarchical clustering and a modified fuzzy cmeans. With the latter, on the basis of 200 most differentially expressed genes in high-grade gliomas in relation to the control group, the samples were divided into two sets according to membership function, in which any sample upon gene expression belongs to set $\mathrm{A}$ with probability $\mathrm{x}$, and to set $\mathrm{B}$ with probability $y$, with an assumption that $x+y=1$. It is noteworthy that sets $\mathrm{A}$ and $\mathrm{B}$ were created upon gene expressions only. At the subsequent stage, the membership parameter was determined by the product of the survival

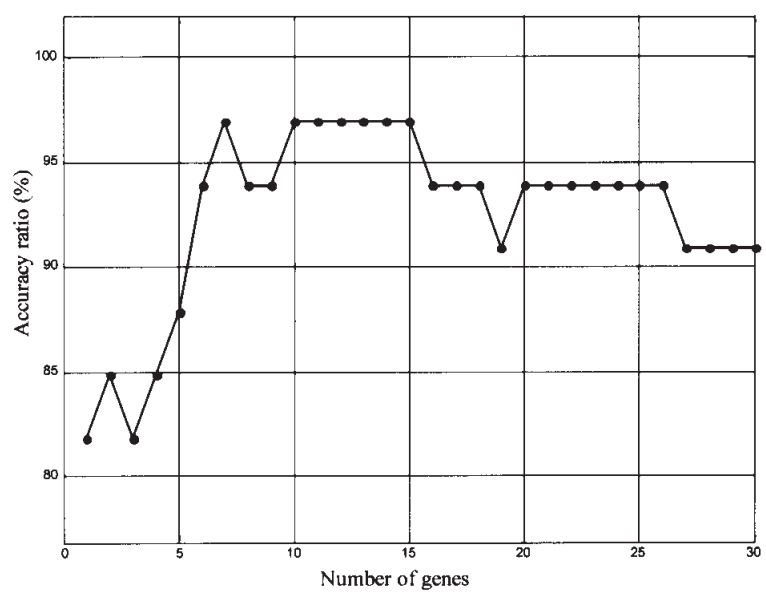

Figure 1. Accuracy ratio of prediction of probes to a proper group (gliomas or controls) using the leave-one-out method (LVSM, Kernel radial) depending on the number of genes used (range, 1-30). Error rate was the lowest with 7 genes used (4 most overexpressed, 3 most underexpressed).

time and the normalized probability value: $\mathrm{r}_{\mathrm{i}}=\mathrm{t}_{\mathrm{i}}\left[\mathrm{x}_{\mathrm{i}} \sqrt{ }\left(\mathrm{x}_{\mathrm{i}}^{2}+\mathrm{y}_{\mathrm{i}}^{2}\right)\right]$; in a few censored cases, their survival time was estimated according to the formula: $t_{i}{ }^{\prime}=\left(t_{\max }+t_{i}\right) / 2$, where $t_{\max }$ is a maximum follow-up (may be censored) in set A or B, accordingly. Afterwards, the samples were sorted out according to the membership parameter, and divided to its median. Next, we built classifiers, and, using the leave-one-out crossvalidation method with a different gene number we found a model with a minimal cross-validation error and the minimum number of genes.

Statistical analyses. Reference points for this study consisted of dates of surgical procedures. January, 2005 was the date of the last follow-up examination. Patients' deaths were end points. Survival time and other factors were analysed with Kaplan-Meier method. The following variables were tested: patient age ( $<40$ years old vs. $\geq 40,<60$ years old vs. $\geq 60$ ), sex, postoperative Karnofsky performance scale (100 vs. others), extent of resection (GTR vs. STR), WHO grade (III vs. IV), radiation dose [low (42 Gy) vs. high (50 Gy and above)], and survival prediction model. Cox's F test was used to analyze the difference between stratified groups, and Cox proportional hazard model, with all factors significant in univariate analysis, was used to find independent factors influencing survival time. Reciprocal associations between parameters were assessed by contingency tables and t-test. For all analyses $\mathrm{p}<0.05$ was accepted as significant. Statistical analysis was performed using Statistica 5.0 (StatSoft, Tulsa, USA).

\section{Results}

As expected, all the gliomas in the study were clearly separated from normal brain samples using the signal-to-noise statistic. On testing a variable number (1-30) of the topmost differentially expressed genes with the leave-one-out method, the cross-validation error rate was the lowest $(0.03)$ when 7 genes ( 4 over- and 3 underexpressed) were used (Fig. 1). The 4 


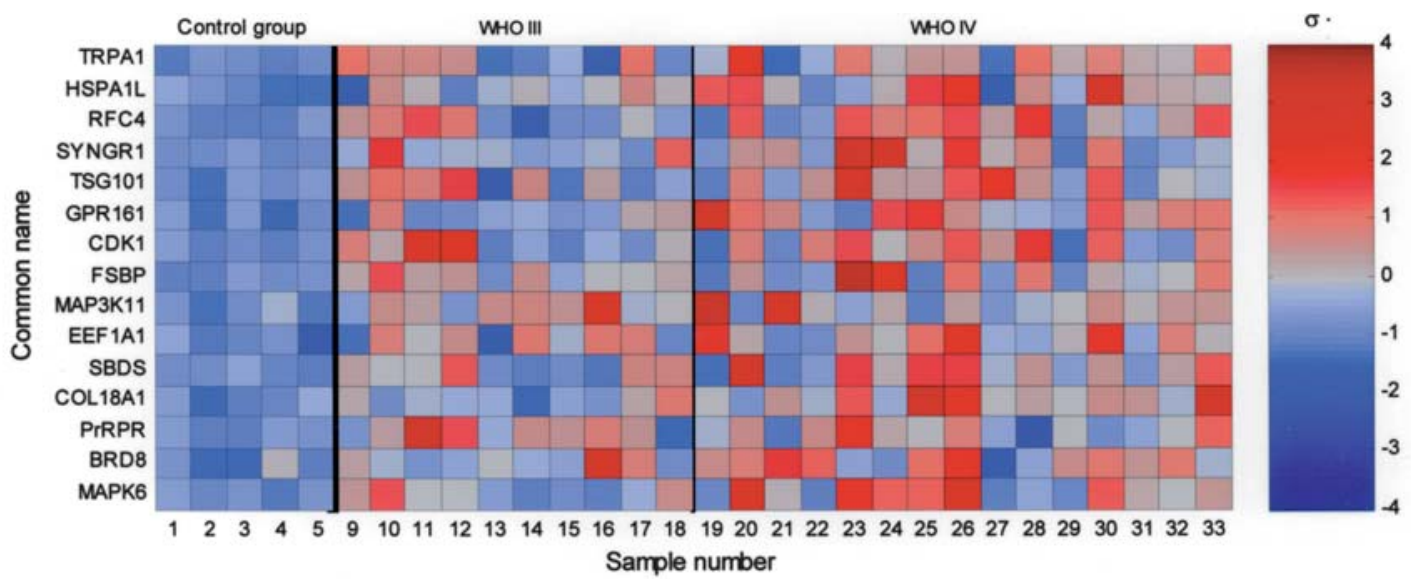

Figure 2. Genes overexpressed in high-grade gliomas in relation to controls, ranked by the signal-to-noise statistic. Colours depict high (red) and low (blue) relative expression to the mean.

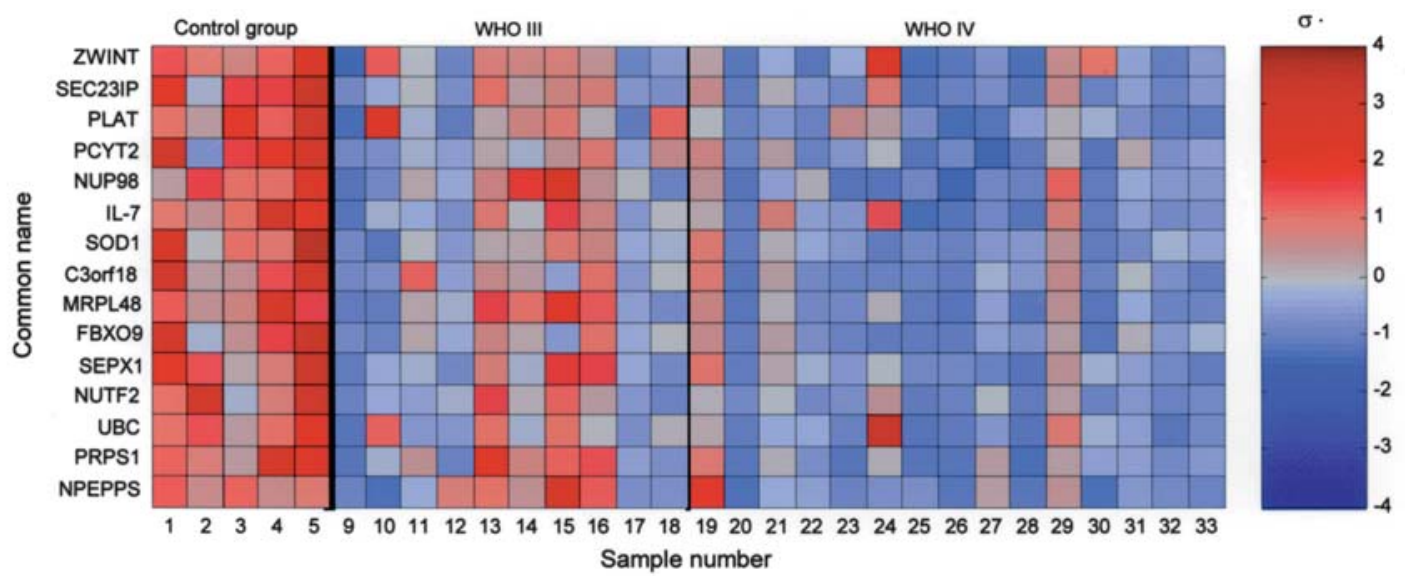

Figure 3. Genes underexpressed in high-grade gliomas in relation to controls, ranked by the signal-to-noise statistic. Colours depict high (red) and low (blue) relative expression to the mean.

most overexpressed genes in gliomas included: TRPA 1, acting as an ion channel, involved in signal transduction, mainly cold nociception $(46,47)$, and recently discovered as a component of the mechanosensitive transduction channel of hair cell in the inner ear (48); HSPA1L, inhibiting apoptosis in gastric (49), prostatic (50), breast, gynaecological and bladder cancers (51), and influencing prognosis; RFC4, encoding replication factor $\mathrm{C} 37 \mathrm{kDa}$ subunit required in elongation of primed DNA templates by DNA polymerase delta and epsilon (52); SYNGR1, whose product is a presynaptic membrane protein associated with presynaptic vesicles (53). Three genes, the most highly underexpressed in gliomas relative to the normal brain, included: ZWINT, playing a significant role in a normal centromere function, and, when depleted, causing an aberrant premature chromosome segregation (54-56); SEC23IP, encoding protein involved in the maintenance of the endoplasmic reticulum-Golgi intermediate compartment and Golgi structures (57); PLAT, encoding tissue-type plasminogen activator, and, when underexpressed in gliomas, may be associated with a hypercoagulated state in intratumoral vessels and its thrombosis (58). Of remarkable interest was also the fifth most overexpressed gene, i.e. CDK1, encoding kinase, which, acting in a complex with cyclin B1 as a mitosis

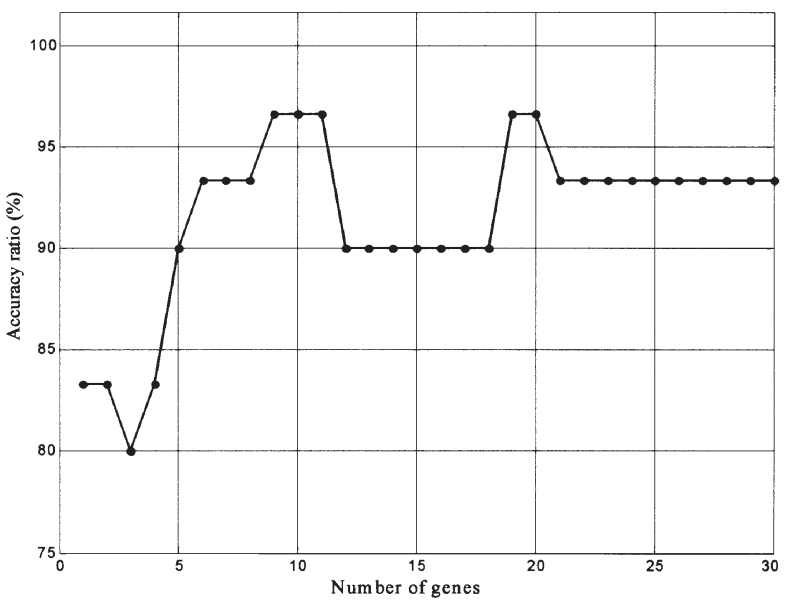

Figure 4. Accuracy ratio of prediction of probes to proper group (high-grade gliomas or controls) using the leave-one-out method (LVSM, Kernel radial) depending on the genes used (range,1-30). Error rate was the lowest with 9 genes used ( 5 most overexpressed, 4 most underexpressed).

promoting factor, plays the key role at the initial stage of mitosis (59). 

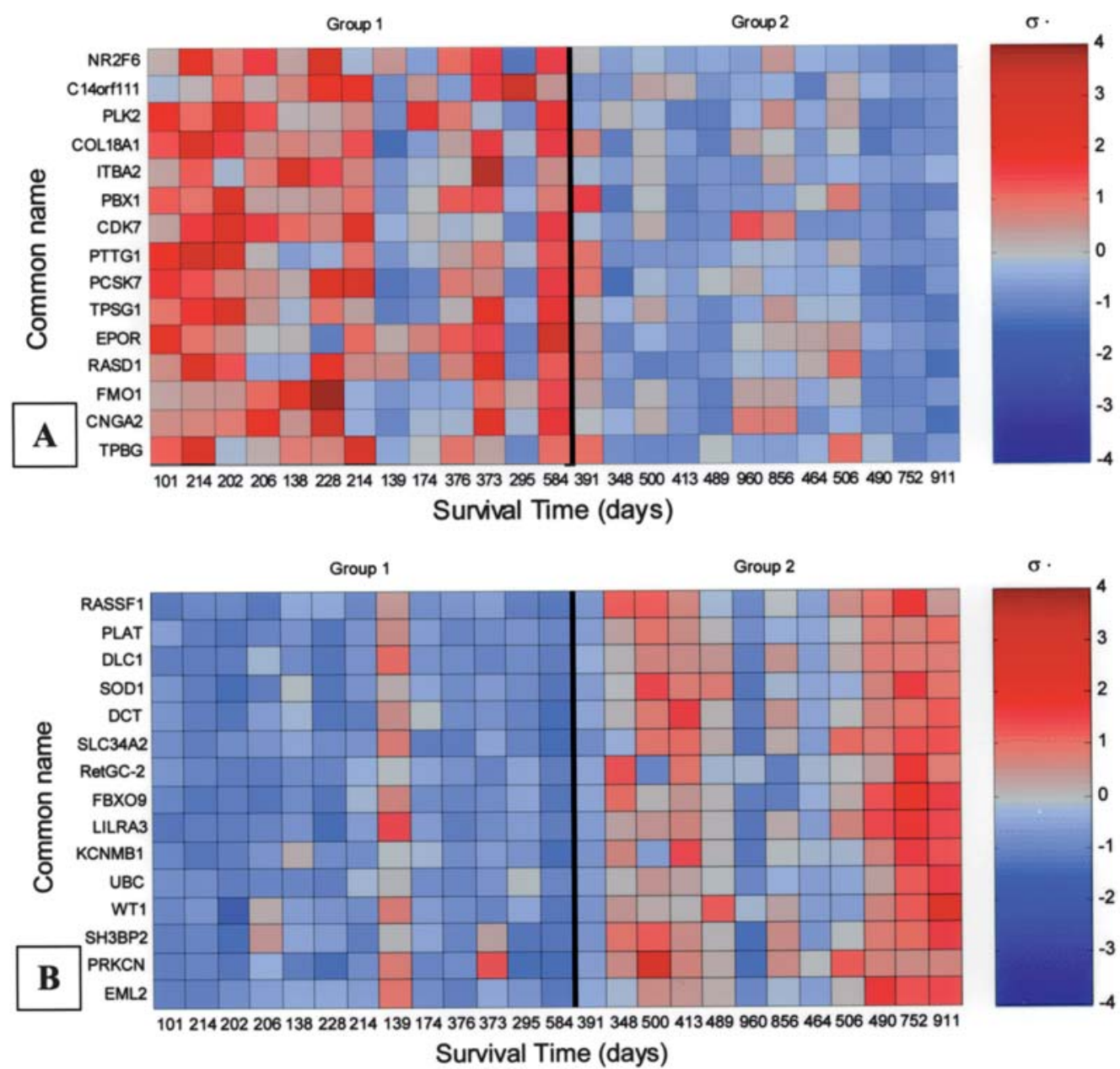

Figure 5. Genes differentially expressed between two groups of high-grade gliomas with a worse or better prognosis, i.e. group 1 and 2 , respectively. The genes were ranked using the signal-to-noise statistic. Colours depict high (red) and low (blue) relative expression to the mean. A and B show 15 most overand underexpressed genes in both groups, respectively.

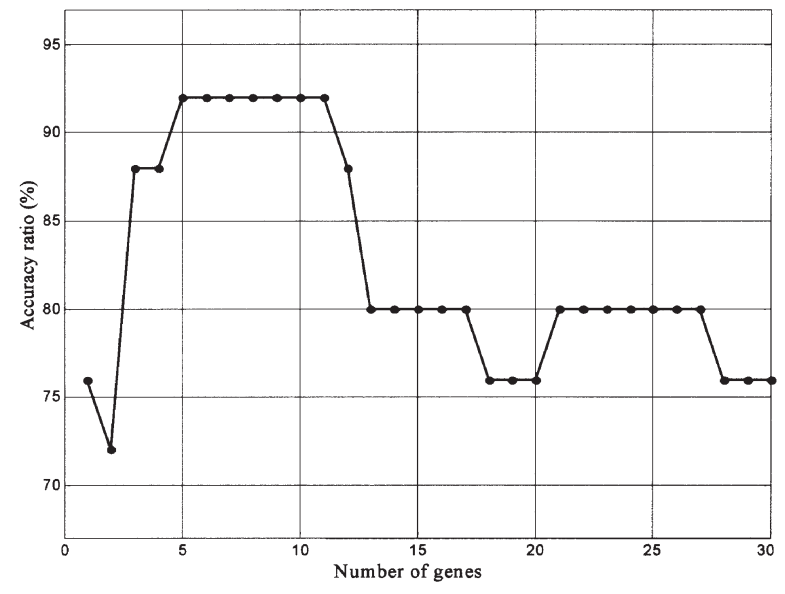

Figure 6. Accuracy ratio of prediction of probes to a proper group (a better or worse prognostic high-grade gliomas) using the leave-one-out method (LVSM, Kernel radial) with respect to the number of genes used (range:1-30). The accuracy rate was the highest with 5-11 most differentially expressed genes.

The topmost differentially expressed genes in high-grade gliomas in relation to normal brain samples were very similar to those in all gliomas, with only few exceptions (Figs. 2 and 3). The cross-validation accuracy was $96.7 \%$ when 9 genes were applied (5 overexpressed and 4 underexpressed) (Fig. 4).
Apart from the 7 genes mentioned above, of importance in this distinction were also the TSG101 (the fifth most overexpressed gene), whose aberrant splicing or mutations are associated with breast cancer $(60,61)$, and PCYT2 (the fourth most underexpressed gene), encoding an enzyme involved in membrane phospholipid synthesis (62).

Grade II tumours (according to WHO classification) were excluded from the survival analysis, since there were only three patients with a short follow-up in this group, and in view of a known, more favourable prognosis than in high-grade gliomas. In order to find genetic profiles correlated with survival, we first investigated whether hierarchical clustering might divide high-grade gliomas into two groups with different prognoses. Although tumours were clustered in two groups distinguishable by gene expression, the survival analysis showed no difference between them. After a failed unsupervised method, we used a partly supervised one known as 'fuzzy c-means' which combines information resulting from gene expression and that on survival. The most overand underexpressed genes in the two resulting groups: the former with a worse, and the latter, with a better prognosis, are displayed in Fig. 5. Survival group 1 included 2 tumours grade III and 11 tumours grade IV, whereas survival group 2 consisted of 8 gliomas grade III and 4 gliomas grade IV. The accuracy ratio of prediction of withheld samples to a proper 


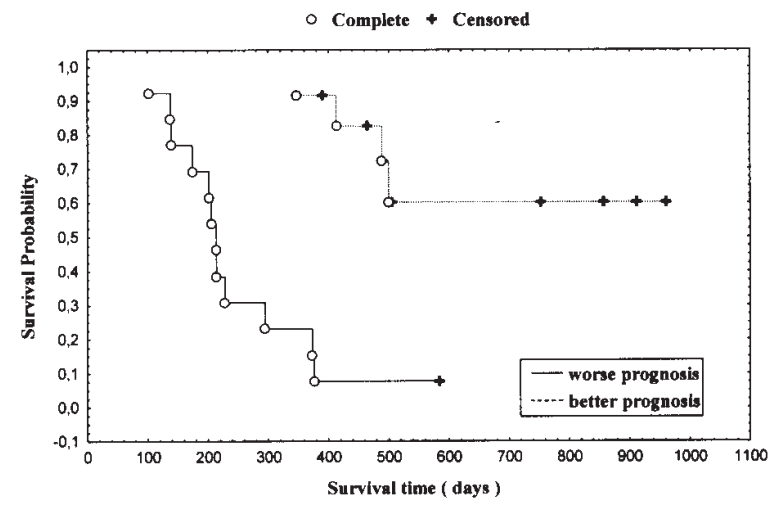

Figure 7. Kaplan-Meier curves for two patient groups divided according to gene expression profiles; Cox's F test: $\mathrm{p}=0.0035$.

group (worse or better survival) using the leave-one-out method (LSVM, Kernel RBF) dependent on the number of genes used, is shown in Fig. 6. As can be seen, from 5 to 11 most differentially expressed genes represent the optimum number of genes with which the SVM classifier may predict a class of withheld samples with a high accuracy $(92 \%)$.

Survival predictor based on gene expression was significant in the univariate survival analysis $(\mathrm{p}=0.0035)$; Kaplan-Meier curves displaying the difference in survival are shown in Fig. 7. Our further attempt was to find association between clinical parameters and survival in high-grade gliomas. Median survival was 498 days in tumours grade III, and 295 days in gliomas grade IV. The difference confirms that the WHO grade is an important predictor of survival $(\mathrm{p}=0.0029)$. A younger age $(<40$ years) was correlated with a longer survival time ( $\mathrm{p}=0.027)$; the age $\geq 60$ years showed the opposite $(\mathrm{p}=0.0038)$. Radiotherapy was used in all high-grade glioma patients. A higher postoperative radiation dose (50 Gy or 62 Gy) vs. a lower dose (42 Gy) was also associated with a more favourable prognosis $(\mathrm{p}=0.0042)$. Differences in survival time were also found in correlation with the first symptom or sign of disease (neurological deficit vs. other symptoms or signs; $\mathrm{p}=0.018)$, and in postoperative KPS score (100 points vs. others $)(p=0.043)$. No other parameters were associated with survival: $\operatorname{sex}(\mathrm{p}=0.11)$, extent of operation (GTR vs. STR; $\mathrm{p}=0.14$ ), epileptic seizure as the first symptom of disease vs. other symptoms and signs $(\mathrm{p}=0.4)$, history duration dichotomized between median $(p=0.29)$, use, or not, of chemotherapy $(\mathrm{p}=0.35)$.

Multivariate Cox regression analysis including a gene expression predictor and all significant clinical factors disclosed that all the other parameters, including WHO grading, become insignificant with gene expression profiling, and that the latter one remained a sole independent predictor of survival $(p=0.007)$. It was also found that a higher dose of postoperative radiation $(\mathrm{p}=0.098)$ tends to exhibit a longer survival on multivariate analysis. Two groups of tumours divided with a gene expression pattern, except for WHO grading ( $\mathrm{p}=0.015)$, did not differ by other factors: age, history duration, first symptom, extent of resection, postoperative KPS score, radiation dose, the use of chemotherapy. The better prognosis group included a higher number of WHO grade III gliomas, and in the worse survival group there were more WHO grade IV gliomas. Apart from a more frequently used lower dose of radiation in older patients ( $>60$ years), and more cases with GTR in WHO grade IV than WHO grade III, no significant associations were found among clinical parameters.

\section{Discussion}

A correct histopathological diagnosis is crucial in prognosis $(6,29,36,63)$, and what is even more important, in susceptibility of some gliomas to chemotherapy $(29,64)$. Results are frequently subjective, and there is significant disagreement among neuropathologists. The answer to the question how to best and accurately identify tumours, may be is found in the domain of molecular technology (65-67). The challenge for molecular biology is to move the burden of histopathological assessment from classical techniques onto molecular methods. As shown by Nutt et al (68), classification of glioblastomas and nonclassic anaplastic oligodendrogliomas based on gene expression shows a significantly better correlation with survival than histological classification; due to this fact the former method may seem to be more robust. In our study, gene expression profiles clearly separated gliomas or high-grade gliomas from normal brain samples, and revealed that among the most overexpressed genes, many are involved in signal transduction and transcription or translation activity, e.g., TRPA1, RFC4, MAP3K11, BRD8, GPR161, PrRPR, EEF1A, MAP3K6. A better understanding of the significance of the most overexpressed, and also the most underexpressed genes in the pathogenesis of gliomas might enhance development of new treatment techniques. It is noteworthy that some of these overexpressed genes encode proteins involved in the G-protein signal transduction cascade, in which, activated G-proteins such as ras, are responsible for activation of serine-kinase kinases such as raf, and subsequently, for activation of MEK and MAPK, which, finally, results in alteration of gene transcription (69-72). An aberrant ras/raf/MEK/MAPK pathway plays an important role in malignant transformation, resistance to apoptosis, and enhanced glioma motility, and might be a target of antiglioma therapy $(69,71,72)$. Enhanced ras signaling is also partially responsible for radioresistance of some gliomas (30). Despite the absence of ras mutations in gliomas, contrary to mutations found in other cancers (69-72), overexpression of genes associated with ras signaling in our study results suggests its substantial role in gliomagenesis. HSPA1L, the second most overexpressed gene in gliomas and high-grade gliomas, apart from its known antiapoptotic influence in other cancers (49), has been recently discovered as expressed also in astrocytomas, and might be associated with resistance to apoptosis induced by chemotherapy, and, in this way, essential for prognosis (Tsogka S, 13th Congress of WFNS, 2005). ZWINT, the most underexpressed gene in our study, is essentially involved in a normal centromere function; its underexpression in tumours might cause an aberrant premature chromosome segregation resulting in aneuploidy in daughter cells (54-56). Oxidative stress damaging intracellular structures may be an initiating event in many diseases, including cancers. One of antioxidant enzymes is SOD1, mutated in amyotrophic lateral sclerosis (73), but also underexpressed in prostate cancers (74). Its underexpression in gliomas may be of significance in gliomagenesis. IL-7, a cytokine regulating B and T cell development, 
was also underexpressed in our cohort study. IL-7 decreases tumorigenicity in mice gliomas (75), and positively influences TIL infiltration in human colorectal cancer (76). Therapeutic implications of these findings might be worth defining.

Despite a grave prognosis in all high-grade gliomas $(1,4,6-8,21,36,63)$, some variability in survival has been noted $(2,3,5)$. It is very likely that in the near future also prognosis in high-grade gliomas based on clinical factors and histopathological evaluation, will, at least partially, be replaced by prognosis based on gene expression $(12,68)$. A vital issue in gliomas is to find out which of them will respond to therapy with their growth slackened, and which ones, despite surgery, radio- and chemotherapy will quickly progress, and the patient will die in a few months. Some factors, e.g., extension of resection and postoperative KPS score, will probably still have a prognostic influence, since they are independent of the biology of gliomas. It is difficult to imagine that the importance of gross total resection, in contrast to a partial resection or biopsy, will have completely disappeared, but other parameters related to tumour behaviour, e.g., age, sex, WHO grading, might be replaced by gene expression profile. At present, contrary to other cancers (77-80) there is no sole glioma marker associated with prognosis or useful in controlling disease progression. Some molecular alterations discovered so far, are associated with the survival time, i.e. LOH 10q, LOH 1p, LOH 19q, PTEN mutations $(2,5,8,13,21,26,28-37)$ or those related to response to chemotherapy, i.e. CDKN2A loss, LOH 1p, LOH 19q (21,26,28-31), indicating that gene expression profiling of gliomas may be valuable in clinical practice. We have hypothesized that gene expression profiling in high-grade gliomas may allow distinguishing two groups of tumours with different prognoses. Results show that such grading is possible and prognosis of high-grade gliomas may be predictable based on the differences in gene expression. Among the 5-11 genes differentiating the worse and better survival groups with a good cross-validation accuracy, probably more interesting ones are those underexpressed in gliomas. In worse survival tumours, the most underexpressed gene relative to those with better survival ones was the tumor suppressor RASSF1, which normally interacts with cdc20, an activator of APC (anaphase promoting complex), resulting in inhibition of APC and stopping the cell cycle at the level of G1/S transition $(81,82)$. RASSF1 negatively regulates cell cycle progression also by inhibiting accumulation of cyclin D1 protein (83). The second most underexpressed gene was PLAT, its underexpression is linked with necrosis and brain oedema in malignant gliomas (58). The third gene was tumour suppressor gene, DLC1. Its deletion or down-regulation have been observed in cancer of the breast (84), lung (85) prostate (86) and liver (87). SOD1 mentioned above, as well as DCT, the fifth most underexpressed gene in the worse survival, also shows an oxidoreductase activity apart from its involvement in melanin biosynthesis from tyrosine (88). Among the most overexpressed genes in the worse survival tumours, the first one was NR2F6 encoding a protein very similar to steroid and thyroid receptors, and involved in regulation of transcription (89); the third most overexpressed gene, PLK2, plays a role in cell cycle regulation and is involved in embryonic development (90).
Currently, clinical factors recognized as those affecting prognosis include WHO grade, age, extent of resection, and KPS status. WHO grading is the only axiom used at present $(4,6)$, which was also confirmed in our study. The usefulness of other factors is questionable, with some disagreements in investigations. We have found a shorter survival for patients with neurological deficit as the first symptom of disease. In our cohort of patients, age was also found to be a significant prognostic factor, which is consistent with other studies $(1,4,6,7,9-11)$. Gross total vs. subtotal resection did not influence prognosis, contrary to other reports $(1,9,10)$. Previous studies on the effect of postoperative KPS score upon prognosis presented various conclusions. Some studies indicated an advantage of a better postoperative status on time of survival $(1,4,6,7,10)$, whereas other authors did not report that relationship $(9,11)$. Our patients with an excellent postoperative status (100 points in KPS), in contrast to patients showing symptoms or signs of disease, had a significantly longer survival time. Finally, a higher radiation dose showed an advantage in patient survival (4). No differences in survival related to sex, history duration, epileptic event as the first sign, and use of chemotherapy were found in univariate analysis, which was consistent with other reports $(1,10,11)$. Multivariate analysis showed that only the gene predictor remained significant, whereas others, at the presence of gene expression profiling, became insignificant. The better survival in patients with high-grade gliomas is suggestive of potentially more differentiated tumours; not surprisingly, that group with better prognosis was found to have more grade III tumours than those of grade IV, contrary to a worse prognosis group in which more malignant according WHO grading tumours prevailed.

In conclusion, gene expression signatures distinguish gliomas or high-grade gliomas from a normal brain with good cross-validation error rates. Survival time in patients with high-grade gliomas is predictable from gene expression; clinical factors at the presence of the gene expression predictor become insignificant in multivariate analysis.

\section{Acknowledgements}

Sponsored by grant No. 3 P 05C 05724 from the Polish State Committee of Scientific Research, 2003-2006.

\section{References}

1. Barker FG, Prados MD, Chang SM, Gutin PH, Lamborn KR, Larson DA, Malec MK, McDermott MW, Sneed PK, Wara WM and Wilson CB: Radiation response and survival time in patients with glioblastoma multiforme. J Neurosurg 84: 442-448, 1996.

2. Burton EC, Lamborn KR, Feuerstein BG, Prados M, Scott J, Forsyth P, Passe S, Jenkins RB and Aldape KD: Genetic aberrations defined by comparative genomic hybridization distinguish long-term from typical survivors of glioblastoma. Cancer Res 62: 6206-6210, 2002.

3. Burton EC, Lamborn KR, Forsyth P, Scott J, O'Campo J, Uyehara-Lock J, Prados M, Berger M, Passe S, Uhm J, O'Neill BP, Jenkins RB and Aldape KD: Aberrant p53, mdm2, and proliferation differ in glioblastomas from long-term compared with typical survivors. Clin Cancer Res 8: 180-187, 2002.

4. Devaux BC, O'Fallon JR and Kelly PJ: Resection, biopsy, and survival in malignant glial neoplasms: a retrospective study of clinical parameters, therapy and outcome. J Neurosurg 78: 767-775, 1993. 
5. Ino Y, Zlatescu MC, Sasaki H, MacDonald DR, StemmerRachamimov AO, Jhung S, Ramsay DA, von Deimling A, Louis DN and Cairncross JG: Long survival and therapeutic response in patients with histologically disparate high-grade gliomas demonstrating chromosome 1 p loss. J Neurosurg 92: 983-990, 2000.

6. Laws E, Parney I, Huang W, Anderson F, Morris A, Asher A, Lillehei K, Berenstein M, Brem H, Sloan A, Berger M and Chang S: Survival following surgery and prognostic factors for recently diagnosed malignant glioma: data from Glioma Outcome Project. J Neurosurg 99: 467-473, 2003.

7. Polin RS, Marko NF, Ammerman MD, Shaffrey ME, Huang W, Anderson FA, Caputy AJ and Laws ER: Functional outcomes and survival in patients with high-grade gliomas in dominant and non-dominant hemispheres. J Neurosurg 102: 276-283, 2005.

8. Smith JS, Tachibana I, Passe SM, Huntley BK, Borell TJ, Iturria N, O'Fallon JR, Schaefer PL, Scheithauer BW, James CD, Buckner JC and Jenkins RB: PTEN mutation, EGFR amplification and outcome in patients with anaplastic astrocytoma and glioblastoma multiforme. J Natl Cancer Inst 93: 1246-1256, 2001.

9. Batchelor TT, Betensky RA, Eposito JM, Pham LDD, Dorfman MV, Piscatelli N, Jhung S, Rhee D and Louis DN: Age-dependent prognostic effects of genetic alterations in glioblastoma. Clin Cancer Res 10: 228-233, 2004.

10. Lacroix M, Abi-Said D, Fourney D, Gokaslan Z, Shi W, De Monte F, Lang F, McCutcheon I, Hassenbusch S, Holland E, Hess K, Michael C, Miller D and Sawaya R: A multivariate analysis of 416 patients with glioblastoma multiforme: prognosis, extent of resection, and survival. J Neurosurg 95: 190-198, 2001

11. Shrieve DC, Alexander E III, Black PM, Wen PY, Fine HA, Kooy HM and Loeffler JS: Treatment of patients with primary glioblastoma multiforme with standard postoperative radiotherapy and radiosurgical boost: prognostic factors and longterm outcome. J Neurosurg 90: 72-77, 1999.

12. Rich JN, Hans C, Jones B, Iversen ES, McLendon RE, Rasheed BKA, Dobra A, Dressman HK, Bigner DD, Nevins JR and West M: Gene expression profiling and genetic markers in glioblastoma survival. Cancer Res 65: 4051-4058, 2005.

13. Hill C, Hunter SB and Brat DJ: Genetic markers in glioblastoma: prognostic significance and future therapeutic implications. Adv Anat Pathol 10: 212-217, 2003.

14. Nakamura M, Konishi N, Tsunoda S, Nakase H, Tsuzuki T, Aoki H, Sakitani H, Inui T and Sakaki T: Analysis of prognostic and survival factors related to treatment of low-grade astrocytomas in adults. Oncology 58: 108-116, 2000.

15. Stander M, Peraud A, Leroch B and Kreth FW: Prognostic impact of TP53 mutation status for adult patients with supratentorial World Health organization grade II astrocytoma or oligoastrocytoma: a long-term analysis. Cancer 101: 1028-1035, 2004.

16. Backlund LM, Nilsson BR, Goike HM, Schmidt EE, Liu L, Ichimura K and Collins VP: Short postoperative survival for glioblastoma patients with a dysfunctional $\mathrm{Rb} 1$ pathway in combination with no wild-type PTEN. Clin Cancer Res 9: 4151-4158, 2003.

17. Birner P, Piribauer M, Fischer I, Gatterbauer B, Marosi C, Ungersbock K, Rossler K, Budka H and Haimfellner JA: Prognostic relevance of $\mathrm{p} 53$ protein expression in glioblastoma. Oncol Rep 9: 703-707, 2002.

18. Kirla R, Salminen E, Huhtala S, Nuutinen J, Talve L, Haapasalo H and Kalim H: Prognostic value of the expression of tumor suppressor genes p53, p21, p16 and pRb, and Ki-67 labelling in high grade astrocytomas treated with radiotherapy. J Neurooncol 46: 71-80, 2000.

19. Kraus JA, Glesmann N, Beck M, Krex D, Klockgether T, Schackert G and Schlegel U: Molecular analysis of the PTEN, TP53 and CDKN2A tumor suppressor genes in long-term survivors of glioblastoma multiforme. J Neurooncol 48: 89-94, 2000.

20. Kraus JA, Wenghoefer M, Glesmann N, Mohr S, Beck M, Schmidt MC, Schroder R, Berweiler U, Roggendorf W, Diete S, Dietzmann K, Heuser K, Muller B, Fimmers R, von Deimling A and Schlegel U: TP53 gene mutations, nuclear p53 accumulation, expression of Waf/p21, bcl-2, and CD95 (APO-1/Fas) proteins are not prognostic factors in de novo glioblastoma multiforme. J Neurooncol 52: 263-271, 2001.

21. Louis DN, Holland EC and Cairncross JG: Glioma classification: a molecular reappraisal. Am J Pathol 159: 779-786, 2001.
22. Newcomb EW, Cohen H, Lee SR, Bhalia SK, Bloom J, Hayes RL and Miller DC: Survival of patients with glioblastoma multiforme is not influenced by altered expression of p16, p53, EGFR, MDM2 or bcl-2 genes. Brain Pathol 8: 655-667, 1998.

23. Peraud A, Kreth FW, Wiestler OD, Kleihues P and Reulen HJ: Prognostic impact of TP53 mutations and p53 protein overexpression in supratentorial WHO grade II astrocytomas and oligoastrocytomas. Clin Cancer Res 8: 1117-1124, 2002.

24. Rainov NG, Dobberstein KU, Bahn H, Holzhausen HJ, Lautenschlager C, Heidecke V and Burkert W: Prognostic factors in malignant glioma: influence of overexpression of oncogene and tumor-suppressor gene products on survival. J Neurooncol 35: 13-28, 1997

25. Simmons ML, Lamborn KR, Takahashi M, Chen P, Israel MA, Berger MS, Godfrey T, Nigro J, Prados M, Chang S, Barker FG II and Aldape K: Analysis of complex relationships between age, p53, epidermal growth factor receptor, and survival in glioblastoma patients. Cancer Res 61: 1122-1128, 2001.

26. Smith JS and Jenkins RB: Genetic alterations in adult diffuse glioma: occurrence, significance, and prognostic implications. Front Biosc 5: 213-231, 2000.

27. Onel $\mathrm{K}$ and Cordon-Cardo C: MDM2 and prognosis. Mol Cancer Res 2: 1-8, 2004.

28. Cairncross JG, Ueki K, Zlatescu MC, Lisle DK, Finkelstein DM, Hammond RR, Silver JS, Stark PC, MacDonald DR, Ino Y, Ramsay DA and Louis DN: Specific genetic predictors of chemotherapeutic response and survival in patients with anaplastic oligodendrogliomas. J Natl Cancer Inst 90: 1473-1479, 1998.

29. Hartmann C, Mueller W and von Deimling A: Pathology and molecular genetics of oligodendroglial tumors. J Mol Med 82: 638-655, 2004.

30. Rao RD and James CD: Altered molecular pathways in gliomas: an overview of clinically relevant issues. Semin Oncol 31: 595-604, 2004.

31. Sasaki H, Zlatescu MC, Betensky RA, Ino Y, Cairncross JG and Louis DN: PTEN is a target of chromosome 10q loss in anaplastic oligodendrogliomas and PTEN alterations are associated with poor prognosis. Am J Pathol 159: 359-367, 2001.

32. Smith JS, Perry A, Borell TJ, Lee HK, O'Fallon J, Hosek SM, Kimmel D, Yates A, Burger PC, Scheithauer BW and Jenkins RB: Alterations of chromosome arms $1 p$ and $19 q$ as predictors of survival in oligodendrogliomas, astrocytomas, and mixed oligoastrocytomas. J Clin Oncol 18: 636-645, 2000.

33. Sano T, Lin H, Chen X, Langford LA, Koul D, Bondy ML, Hess KR, Myers JN, Hong YK, Yung WKA and Steck PA: Differential expression of MMAC/PTEN in glioblastoma multiforme: relationship to localization and prognosis. Cancer Res 59: $1820-1824,1999$.

34. Zhou YH, Tan F, Hess KR and Yung WK: The expression of PAX6, PTEN, vascular endothelial growth factor and epidermal growth factor receptor in gliomas: relationship to tumor grade and survival. Clin Cancer Res 9: 3369-3375, 2003.

35. Ohgaki H, Dessen P, Jourde B, Horstmann S, Nishikawa T, Di Patre PL, Burkhard C, Schuler D, Probst-Hensch NM, Maiorka PC, Baeza N, Pisani P, Yonekawa Y, Yasargil MG, Lutolf UM and Kleihues P: Genetic pathways to glioblastoma: a population based study. Cancer Res 64: 6892-6899, 2004.

36. Ohgaki $\mathrm{H}$ and Kleihues P: Population-based studies on incidence, survival rates, and genetic alterations in astrocytic and oligodendroglial gliomas. J Neuropathol Exp Neurol 64: 479-489, 2005.

37. Wiltshire RN, Herndon JE, Lloyd A, Friedman HS, Bigner DD, Bigner SH and McLendon RE: Comparative genomic hybridization analysis of astrocytomas: prognostic and diagnostic implications. J Mol Diagn 6: 166-179, 2004.

38. Alizadeh AA, Eisen MB, Davis RE, Ma C, Lossos IS and Rosenwald A: Distinct types of diffuse large B-cell lymphoma identified by gene expression profiling. Nature 403: 503-511, 2000.

39. Pomeroy SL, Tamayo P, Gaasenbeek M, Sturla LM, Angelo M, McLaughlin ME, Kim JYH, Goumnerova LC, Black PM, Lau C, Allen JC, Zagzag D, Olson JM, Curran T, Wetmore C, Biegel JA, Poggio T, Mukherjee S, Rifkin R, Califano A, Stolovitzky G, Louis DN, Mesirov JP, Lander ES and Golub TR: Prediction of central nervous system embryonal tumour outcome based on gene expression. Nature 415: 436-442, 2002.

40. Ramaswamy S, Ross KN, Lander ES and Golub TR: A molecular signature of metastasis in primary solid tumors. Nat Genet 33 : 49-54, 2003. 
41. Sorlie T, Perou CM, Tibshirani R, Aas T, Geisler S, Johnsen H, Hastie T, Eisen MB, van de Rijn M, Jeffrey SS, Thorsen T, Quist H, Matese JC, Brown PO, Botstein D, Eystein Lonning P and Borresen-Dale AL: Gene expression patterns of breast carcinomas distinguish tumor subclasses with clinical implications. Proc Natl Acad Sci USA 98: 10869-10874, 2001.

42. Freije WA, Castro-Vargas FE, Fang Z, Horvath S, Cloughesy T, Liau LM, Mischel PS and Nelson SF: Gene expression profiling of gliomas strongly predicts survival. Cancer Res 64: 6503-6510, 2004.

43. Fuller GN, Hess KR, Rhee CH, Yung WKA, Sawaya RA, Bruner JM and Zhang W: Molecular classification of human diffuse gliomas by multidimensional scaling analysis of gene expression profiles parallels morphology-based classification, correlates with survival, and reveals clinically-relevant novel glioma subsets. Brain Pathol 12: 108-116, 2002.

44. Liang Y, Diehn M, Watson N, Bollen AW, Aldape KD, Nicholas MK, Lamborn KR, Berger MS, Botstein D, Brown PO and Israel MA: Gene expression profiling reveals molecularly and clinically distinct subtypes of glioblastoma multiforme. Proc Natl Acad Sci USA 102: 5814-5819, 2005.

45. Chomczynski P and Sacchi N: Single-step method of RNA isolation by acid guanidinum thiocyanate-phenolchloroform extraction. Anal Biochem 162: 156-159, 1987.

46. Jordt SE, Bautista DM, Chuang HH, McKemy DD, Zygmunt PM, Hogestatt ED, Meng ID and Julius D: Mustard oils and cannabinoids excite sensory nerve fibres through the TRP channel ANKTM1. Nature 427: 260-265, 2004.

47. Story GM, Peier AM, Reeve AJ, Eid SR, Mosbacher J, Hricik TR, Earley TJ, Hergarden AC, Andersson DA, Hwang SW, McIntyre P, Jegla T, Bevan S and Patapoutian A: ANKTM1, a TRP-like channel expressed in nociceptive neurons, is activated by cold temperatures. Cell 112: 819-829, 2003.

48. Corey DP, Garcia-Anoveros J, Holt JR, Kwan KY, Lin SY, Vollrath MA, Amalfitano A, Cheung EL, Derfler BH, Duggan A, Geleoc GS, Gray PA, Hoffman MP, Rehm HL, Tamasauskas D and Zhang DS: TRPA1 is a candidate for the mechanosensitive transduction channel of vertebrate hair cells. Nature 432: 723-730, 2004.

49. Zhao ZG and Shen WL: Heat shock protein 70 antisense oligonucleotide inhibits cell growth and induces apoptosis in human gastric cancer cell line SGC-7901. World J Gastroenterol 11: 73-78, 2005.

50. Jones EL, Zhao MJ, Stevenson MA and Calderwood SK: The 70 kilodalton heat shock protein is an inhibitor of apoptosis in prostate cancer. Int J Hyperthermia 20: 835-849, 2004.

51. Ciocca DR and Calderwood SK: Heat shock proteins in cancer: diagnostic, prognostic, predictive, and treatment implications. Cell Stress Chaperones 10: 86-103, 2005.

52. Loor G, Zhang S-J, Zhang P, Toomey NL and Lee MY: Identification of DNA replication and cell cycle proteins that interact with PCNA. Nucleic Acids Res 25: 5041-5046, 1997.

53. Janz R, Sudhof TC, Hammer RE, Unni V, Siegelbaum SA and Bolshakov VY: Essential roles in synaptic plasticity for synaptogyrin I and synaptophysin I. Neuron 24: 687-700, 1999.

54. Kops GJ, Kim Y, Weaver BA, Mao Y, McLeod I, Yates JR III, Tagaya M and Cleveland DW: ZW 10 links mitotic checkpoint signalling to the structural kinetochores. J Cell Biol 169: 49-60, 2005.

55. Starr DA, Saffery R, Li Z, Simpson AE, Choo KHA, Yen TJ and Goldberg ML: HZwint-1, a novel human kinetochore component that interacts with HZW10. J Cell Sci 113: 1939-1950, 2000.

56. Wang H, Hu X, Ding X, Dou Z, Yang Z, Shaw AW, Teng M, Cleveland DW, Goldberg ML, Niu L and Yao X: Human Zwint-1 specifies localization of Zeste White 10 to kinetochores and is essential for mitotic checkpoint signalling. J Biol Chem 279: 54590-54598, 2004.

57. Tani K, Mizoguchi T, Iwamatsu A, Hatsuzawa K and Tagaya M: p125 is a novel mammalian Sec23p-interacting protein with structural similarity to phospholipid-modifying proteins. J Biol Chem 274: 20505-20512, 1999.

58. Sawaya R, Ramo OJ, Shi ML and Mandybur G: Biological significant of tissue plasminogen activator content in brain tumours. J Neurosurg 74: 480-486, 1991

59. Dirks PB and Rutka JT: Current concepts of neuro-oncology: the cell cycle - a review. Neurosurgery 40: 1000-1015, 1997.

60. Lee MP and Feinberg AP: Aberrant splicing but not mutations of TSG101 in human breast cancer. Cancer Res 57: 3131-3134, 1997.
61. Li L, Li X, Francke U and Cohen SN: The TSG101 tumor susceptibility gene is located in chromosome 11 band p15 and is mutated in human breast cancer. Cell 88: 143-154, 1997.

62. Nakashima A, Hosaka K and Nikawa J: Cloning of a human cDNA for CTP-phosphoethanolamine cytidylyltransferase by complementation in vivo of a yeast mutant. J Biol Chem 272: 9567-9572, 1997.

63. Wong ET, Hess KR, Gleason MJ, Jaeckle KA, Kyritsis AP, Prados MD, Levin VA and Yung WKA: Outcomes and prognostic factors in recurrent glioma patients enrolled onto phase II clinical trials. J Clin Oncol 17: 2572-2578, 1999.

64. Cairncross JG, MacDonald DR and Ramsay DA: Aggressive oligodendroglioma: a chemosensitive tumor. Neurosurgery 31 : 78-82, 1992.

65. Godard S, Getz G, Delorenzi M, Farmer P, Kobayashi H, Desbaillets I, Nozaki M, Diserens AC, Hamou MF, Dietrich PY, Regli L, Janzer RC, Bucher P, Stupp R, De Tribolet N, Domany E and Hegi ME: Classification of human astrocytic gliomas on the basis of gene expression: a correlated group of genes with angiogenic activity emerges as a strong predictor of subtypes. Cancer Res 63: 6613-6625, 2003.

66. Kim S, Dougherty ER, Shmulevich I, Hess KR, Hamilton SR, Trent JM, Fuller GN and Zhang W: Identification of combination gene sets for gliomas classification. Mol Cancer Ther 1: 1229-1236, 2002.

67. Shai R, Shi T, Kremen T, Horvath S, Liau LM, Cloughesy TF, Mischel PS and Nelson SF: Gene expression profiling identifies molecular subtypes of gliomas. Oncogene 22: 4918-4923, 2003.

68. Nutt CL, Mani DR, Betensky RA, Tamayo P, Cairncross JG, Ladd C, Pohl U, Hartmann C, McLaughlin ME, Batchelor TT, Black PM, von Deimling A, Pomeroy SL, Golub TR and Louis DN: Gene expression-based classification of malignant gliomas correlates better with survival than histological classification. Cancer Res 63:1602-1607, 2003.

69. Kapoor GS and O'Rourke DM: Mitogenic signaling cascades in glial tumors. Neurosurgery 52: 1425-1435, 2003.

70. Mammas IN, Zafiropoulos A and Spandidos DA: Involvement of the ras genes in female genital tract cancer. Int J Oncol 26: 1241-1255, 2005

71. Newton HB: Molecular neuro-oncology and the development of targeted therapeutic strategies for brain tumors. Part 1: growth factors and Ras signaling pathways. Expert Rev Anticancer Ther 3: 595-614, 2003.

72. Woods SA, Marmor E, Feldkamp M, Lau N, Apicceli AJ and Boss G: Aberrant $\mathrm{G}$ protein signalling in nervous system tumors. J Neurosurg 97: 627-642, 2002.

73. Rosen DR, Siddique T, Patterson D, et al: Mutations in $\mathrm{Cu} / \mathrm{Zn}$ superoxide dismutase gene are associated with familial amyotrophic lateral sclerosis. Nature 362: 59-62, 1993.

74. Bostwick DG, Alexander EE, Singh R, Shan A, Qian J, Santella RM, Oberley LW, Yan T, Zhong W, Jiang X and Oberley TD: Antioxidant enzyme expression and reactive oxygen species damage in prostatic intraepithelial neoplasia and cancer. Cancer 89: 123-134, 2000.

75. Aoki T, Tashiro K, Miyatake S, Kinashi T, Nakano T, Oda Y, Kikuchi $\mathrm{H}$ and Honjo T: Expression of murine interleukin 7 in a murine glioma cell line results in reduced tumorigenicity in vivo. Proc Natl Acad Sci USA 89: 3850-3854, 1992.

76. Maeurer MJ, Walter W, Martin D, Zitvogel L, Elder E, Storkus W and Lotze MT: Interleukin-7 (IL-7) in colorectal cancer: IL-7 is produced by tissues from colorectal cancer and promotes preferential expansion of tumour infiltrating lymphocytes. Scand J Immunol 45: 182-192, 1997.

77. Bataille R, Boccadoro M, Klein B, Durie B and Pileri A: Creactive protein and beta- 2 microglobulin produce a simple and powerful myeloma staging system. Blood 80: 733-737, 1992.

78. Duffy MJ: Carcinoembryonic antigen as a marker for colorectal cancer: is it clinically useful? Clin Chem 47: 624-630, 2001.

79. Lawicki S, Mroczko B and Szmitkowski M: The tumor markers of breast cancer. Postepy Hig Med Dosw (in Polish) 58: 92-300, 2004.

80. Qin LX and Tang ZY: The prognostic significance of clinical and pathological features in hepatocellular carcinoma. World J Gastroenterol 8: 193-199, 2002.

81. Mathe E: RASSF1A, the new guardian of mitosis. Nat Genet 36: 117-118, 2004.

82. Song MS, Song SJ, Ayad NG, Chang JS, Lee JH, Hong HK, Lee H, Choi N, Kim J, Kim H, Kim JW, Choi EJ, Kirschner MW and Lim DS: The tumour suppressor RASSF1A regulates mitosis by inhibiting the APC-Cdc20 complex. Nat Cell Biol 6: 129-137, 2004. 
83. Shivakumar L, Minna J, Sakamaki T, Pestell R and White MA: The RASSF1A tumor suppressor blocks cell cycle progression and inhibits cyclin D1 accumulation. Mol Cell Biol 22: 4309-4318, 2002.

84. Venter DJ, Ramus SJ, Hammet FM, De Silva M, Hutchins AM, Petrovic V, Price G and Armes JE: Complex CGH alterations on chromosome arm $8 \mathrm{p}$ at candidate tumor-suppressor gene loci in breast cancer cell lines. Cancer Genet Cytogenet 160: 134-140, 2005.

85. Yuan BZ, Jefferson AM, Baldwin KT, Thorgeirsson SS, Popescu NC and Reynolds SH: DLC-1 operates as a tumor suppressor gene in human non-small cell lung carcinomas. Oncogene 23: 1405-1411, 2004.

86. Guan M, Zhou X, Soulitzis N, Spandidos DA and Popescu NC: Aberrant methylation and deacetylation of deleted in liver cancer-1 gene in prostate cancer: potential clinical applications. Clin Cancer Res 12: 1412-1419, 2006.
87. Yuan BZ, Miller MJ, Keck CL, Zimonjic DB, Thorgeirsson SS and Popescu NC: Cloning, characterization, and chromosomal localization of a gene frequently deleted in human liver cancer (DLC-1) homologous to rat RhoGAP. Cancer Res 58: 2196-2199, 1988.

88. Guyonneau L, Murisier F, Rossier A, Moulin A and Beermann F: Melanocytes and pigmentation are affected in dopachrome tautomerase knockout mice. Mol Cell Biol 24: 3396-3403, 2004

89. Miyajima N, Kadowaki Y, Fukushige S, Shimizu S, Semba K, Yamanashi Y, Matsubara K, Toyoshima K and Yamamoto T: Identification of two novel members of erbA superfamily by molecular cloning: the gene products of the two are highly related to each other. Nucleic Acids Res 16: 11057-11074, 1988.

90. Ma S, Charron J and Erikson RL: Role of Plk2 (Snk) in mouse development and cell proliferation. Mol Cell Biol 23: 6936-6943, 2003. 